\title{
鋭/鈍繰返し表示特性を利用した映像符号量削減方式
}

\section{Rate Reduction Method based on Human Visual Perception of Repeatedly Displayed Sharp and Blurred Pictures}

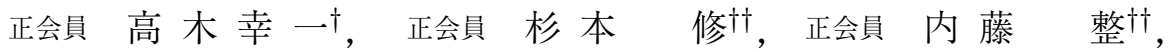

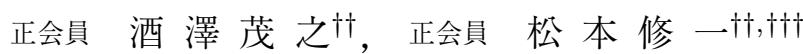

Koichi Takagi ${ }^{\dagger}$, Osamu Sugimoto ${ }^{\dagger \dagger}$, Sei Naito ${ }^{\dagger \dagger}$, Shigeyuki Sakazawa ${ }^{\dagger \dagger}$ and Shuichi Matsumoto ${ }^{\dagger \dagger, \dagger^{\dagger \dagger}}$

\begin{abstract}
This paper proposes a rate reduction method for high frame-rate picture coding based on repeatedly displaying sharp and blurred pictures. Our contribution is a picture coding method utilizing a spatiotemporal frequency model derived from human perceptual limitation of high frame-rate pictures. This method removes the high frequency parts of residual coefficients based on the spatiotemporal properties derived from local image data. Experimental results show that the proposed method achieves an average of $15 \%$ bit savings over the conventional MPEG-4 AVC/H.264 coding method without subjective degradation.
\end{abstract}

キーワード：高フレームレート，鋭/鈍再生制御，時空間視覚特性モデル

\section{1. まえがき}

近年，IPTV やデジタル放送に代表される映像配信・放 送サービスでは，HDTVクラスの解像度を持つコンテン ツが主流となってきている.さらに, 将来的には, 映像コ ンテンツの高解像度化, 高フレームレート化が進み, 高臨 場感が得られるサービスの実現が期待されている。特に, 高フレームレート化の方に着目すると, 現在, 一般的に放 送で用いられている $60 \mathrm{i}(59.94 \mathrm{i})$ にとどまらず，プログレッ シブで $60 \mathrm{~Hz}(60 \mathrm{p})$ 以上の高フレームレート化の必要性に 関する言及がされている ${ }^{1)}$. 以上のように, 高解像度の映 像を $60 \mathrm{p}$ で見ることへの要求が高まる中, シングル SDI で 1080/60p 信号を伝送する 3G-SDI 方式 ${ }^{2)}$ が規格化さ れ，さらに，民生用でも $1080 / 60 \mathrm{p}$ をサポートするテレビ， カムコーダ, 記録媒体等が多数出荷され始めている ${ }^{3)}$.ま た，これらの機器では，最新の符号化技術である MPEG-4 $\mathrm{AVC}($ 以下 $\mathrm{AVC}) / \mathrm{H} .264$ をサポートしていることがほとん

2011 年 9 月 30 日受付, 2012 年 1 月 31 日再受付, 2012 年 3 月 12 日採録 $\dagger$ KDDI 株式会社

( ₹ 102-8460 千代田区飯田橋 3-10-10)

††株式会社 KDDI 研究所

（テ356-8502 埼玉県ふじみ野市大原 2-1-15）

††一般社団法人日本ケーブルラボ

（= 108-0071 港区白金台 3-19-1 興和白金台ビル 5F

$\dagger$ KDDI Corporation

(3-10-10, Iidabashi, Chiyoda-ku, Tokyo 102-8460, Japan.)

$\dagger \dagger$ KDDI R\&D Labs. Inc.

(2-1-15, Ohara, Fujimino-shi, Saitama 356-8502, Japan.)

$\dagger \uparrow \dagger$ Japan Cable Laboratories

(3-19-1 Shirokane-dai, Minato-ku, Tokyo 108-0071, Japan)
どである。そこで，本稿では，特に $1080 / 60 p$ を符号化対 象とし，標準的な AVC/H.264 デコーダで復号可能である ことを条件とした高効率符号化方式を検討する。

一方，フレームレートが高くなればなるほど，単位時間 あたりの画像データが増えるため，当該データの符号化・ 圧縮のさらなる効率化が必須となる。そこで，増加した画 像デー夕の符号量を削減することが必要になるが，そのた めの方法として, (1) 画像の性質を利用する方法, および （2）人間の視覚特性を利用する方法が考えられる.

（1）について，画像の時間方向の圥長性を除去する上 で，従来から利用されているフレーム間予測符号化方式が 有効である。フレームレートが高くなればなるほど，隣接 フレーム間の相関が高くなり，フレーム間予測の効率が高 くなるためである。なお，この方法には，可逆圧縮のもの と非可逆圧縮のものがあり，後者は一般的に符号化ビット レートと歪みの関係で最適な符号化が行われる。特に，文 献 4)5) では，高フレームレート時の符号化効率向上を目的 とし，フレームレートと情報量の間の定量的な評価を行え るようにするために，フレームレートとフレーム間差分信 号の情報量の関係を解析し，モデルの形で導出している.

一方（2）は，人間の目に見えない歪みを許容する方法 であり，一般的に非可逆圧縮である。この方法では，人間 の目に見えない画像成分を除去することにより，符号量の 削減を行う*。その中で，文献 6)～8) では，鮮鋭な画像と

*プログレッシブ走査からインタレース走査に置換することで，原信号の サイズを $1 / 2$ にする方法も本項目の一つに属すと考えられるが, 前述の 通り，60i を 60p にしようとする動きがあることから，ここでは議論の 
ぼけた画像が繰り返し表示される（以下「鋭/鈍繰返し表 示」と書く）ときに鮮鋭な画像と同程度の主観画質が得ら れる現象を用いて符号量削減を図っている。

Fujibayashi ら ${ }^{6)}$ は, 上記現象を説明するためのモデル を構築した上で, 同モデルを映像符号化の枠組みに適用し, 特に高速な動きを持つシーケンスに対し有効であることを 示している ${ }^{7)}$. ところが, 前述のモデルをデコーダ内で再 構築する必要があるため, AVC/H.264 等既存の符号化方 式にそのまま適用することができない.

一方, 吹抜 ${ }^{8)}$ も, 時空間視覚特性モデルの上で同現象を 説明しており, GOP 構造の構成の方法を含め, 符号化へ の導入可能性について言及している。ところが，1枚おき に低解像度画像を符号化することは，時間方向の相関が低 くなり，(1)で述べたフレーム間予測符号化の効率を減じる ことが懸念される.

そこで，本稿では，（1）で述べたフレーム間予測によ る効率化と（2）で述べた錯視を考慮した符号量削減を AVC/H.264 等既存の符号化規則の下で共に利用できるよ うにするために，前述の文献 8) の考え方を応用する。そし て, 符号化の前処理として鋭/鈍繰返し表示に基づく原理を 適用し，符号量削減を実現する手法を提案する.

以下，2章で鮮鋭な画像とぼけた画像の繰り返し表示に 関する関連研究について説明する. その後，3章でその原 理に基づき符号量を削減するための提案手法について述べ る. 4 章で提案手法の有効性について実験した上でその考 察を行い，5章で本論文をまとめる.

\section{2. 関連 研究}

本章では, 動画像において, 鮮鋭な画像（鋭画像）とぼ けた画像 (鈍画像) が繰り返し表示されるときに鮮鋭な画 像と同程度の主観画質が得られる現象, およびそれに基づ く圧縮の可能性に関する関連研究について述べる.

Fujibayashi ら ${ }^{6)}$ は, Motion Sharpening ${ }^{9)}$ と呼ばれる 錯視（静止状態ではぼけた画像が, 動画として見ると鮮鋭 に見えることがある現象）の一つとして，上述の現象に着 目している。これを同文献では Quasi Motion Sharpening と呼んでいる。その上で，この錯視のメカニズムを視覚マ スキングの観点から解明し，それに基づき，画面全体の動 きの大きさ・平均輝度・パワースペクトルから鈍画像のスペ クトル補正手段，すなわち，どこまでほかしてよいかを示 す指標に相当する空間周波数特性を求める手段を提示して いる.ささらに, Fujibayashiらは，このスペクトル補正手段 を映像符号化に適用している。具体的には，1フレームお きに，原画像と参照メモリー内の画像の両者に対しスペク トル補正を行い，その予測誤差を符号化することで符号量 を削減しており, 特に高速な動きを持つシーケンスに対し 有効であることを示している ${ }^{7)}$.ところが, 画面全体の動き

対象外とする.
など，原画像に基づく情報を別途デコーダに伝送する必要 がある，また，この処理に対応するデコーダを構築する際， 1フレームおきに参照メモリー用の画像を生成するために スペクトル補正演算を行う必要があるなど, AVC/H.264 等既存の符号化方式にそのまま適用することができない.

一方, 吹抜 ${ }^{8)}$ は, 鋭/鈍繰返し表示による錯視を, 視知 覚信号処理工学の立場から時空間周波数領域で解明してい る。鋭/鈍繰返し表示による錯視とは, 例えば, 60p の画像 があった場合に，1フレームおきに鋭画像（高解像度画像， 30 フレーム/秒）と鈍画像（低解像度画像，30 フレーム/ 秒）を繰返すと，全体が鋭画像に見えるというものである. この現象を文献 8) に即して説明すると, すべてのフレーム が鋭画像で構成される $60 \mathrm{p}$ の画像に対する空間水平周波数 $\mu$, 時間周波数 $f$ の時空間周波数スペクトルは図 $\mathbf{1}(\mathrm{a})$ のよ うになる*。ここで, 同図に対し, 図 1(b)に示す通り, 時 間周波数が $60 \mathrm{~Hz}$ となるスペクトルの高域成分を削除する 処理，すなわち，60p で1枚おきに空間領域の高域を削減 する処理を行ったとき, 各成分の時間標本化周波数は鈍画 像成分: $60 \mathrm{~Hz}$, 鋭画像成分: $30 \mathrm{~Hz}$ となり, 視覚通過帯域 (図 1 の (網点) 内) で見ると, 両者のスペクトルは変 わらない.よって, 図1(b)のとおり補正した場合, 視覚的 に, すべてが $60 \mathrm{~Hz}$ 高解像度画像 (鋭画像) の場合と等価 になる。なお, 同文献では, 符号化効率の向上についても 触れている。例えば, 「 $60 \mathrm{p}$ を対象とする MPEGにおける 現象と応用」と題し,

- $\mathrm{M}(\mathrm{GOP}$ 間隔 $)=4$ の場合: $\mathrm{I}[\mathrm{B}] \mathrm{B}[\mathrm{B}] \mathrm{P} \ldots$

- $\mathrm{M}=2$ の場合: $\mathrm{I}[\mathrm{B}] \mathrm{P}[\mathrm{B}] \mathrm{P} \ldots$

において，[B] に相当する picture を低解像度に抑えること により主観画質を落とすことなく，1フレームおきに画像 信号の情報量を削減することができるため, 圧縮効率向上 が期待できると述べられている。ところが，1フレームお きに低解像度画像を符号化することは, 時間方向の相関が 低くなることにもつながるため, 符号化効率が下がること が懸念される，また，同方式では，当該フレームを鋭/鈍い ずれかのフレームと一義的に決定し，鈍フレームでは画面 内で一律の低域通過フィルタを適用することを前提として いる.

\section{3. 提 案 方 式}

本章では，鋭/鈍繰返し表示による錯視の原理を解明す る上で使われている時空間視覚特性モデルを活用し，これ を画面内の局所領域ごとに適用する必要性を述べる。また， 文献 8)より, 同モデルにおいて, 時間・空間周波数が高い 領域は共に人間の視覚の帯域外になることがわかっている ため，本稿では，それに基づき，「視覚通過帯域外に含まれ る雑音は無視できる」という仮説を立てる。そして，時空間

* 視覚通過帯域の水平周波数-垂直周波数空間特性は，視覚特性が等方的な 場合は円形になるが，現実には斜め方向の特性が劣ることからダイヤモ ンド型が近いと言われている ${ }^{8)}$. 




図 1 鋭/鈍画像のスペクトルと伝送周波数特性（簡単のため, 時間－水平周波数成分のみ提示) ${ }^{8)}$

Spectrum for sharp/blurred repetition picture (Only horizontal-temporal domain is shown for simplicity).

特性モデルの映像符号化への導入を簡単に行うために，映 像信号から得られた帯域情報をイントラ予測，および動き 補償予測の残差信号に対し適用し，係数を除去する方法を 提案する。

\section{1 画面一律制御時の問題および局所領域制御のため の時空間特性表現}

前章にも述べた通り，フレームを鋭/鈍どちらにするかを 画面全体で一義的に決定し, 鈍フレームで一律の低域通過 型フィルタ処理を適用する予備実験を実施した。その結果, 映像内の動きの特性により局所的にボケて見える個所が出 てくることを確認した.

その原因を考察するために，60p の信号に対し 1 フレー ムおきに高域成分を除去する場合を想定すると，前述の処 理は，画面内の全領域に対し，実効時間周波数，すなわち 画面内の全オブジェクトの時間周波数が $60 \mathrm{~Hz}$ であるとし て図 1(b) の処理を行うことに相当する．ここで，60p の信 号において，静止領域は時間的な信号変化がないため，時 間周波数が低い領域にエネルギーがある。一方、動きのあ る物体の存在している箇所については，動きが速いほど時 間周波数が高くなる．以上のように，実効時間周波数は画 面内領域ごとに異なるため，前述の処理により，実効時間 周波数が $60 \mathrm{~Hz}$ ではない個所において，過度に空間解像度 を落とすことになる。その結果, 視覚通過帯域に存在する 信号を削除する問題が発生する。

以上の理由から，本問題を解決するため，フレーム内の 局所領域ごとに時間周波数を求め, それに対し除去してよ い空間周波数成分を細かく設定する必要がある。そこで，以 下で本処理を局所的に行うための方法について述べる.

まず，本処理の対象となるフレームの各 MB（マクロブ ロック）に対し，図 2 に示す通りそれぞれ過去 $N_{B}$ フレー ム, 未来 $N_{F}$ フレームの同一位置の画素值をあわせて, 時 空間 3 次元映像信号として取得する. 次に, この 3 次元映 像信号に対し 3 次元 FFT を適用し，時空間周波数特性を求 める. 求められた時空間周波数特性の結果を図 1 にプロッ

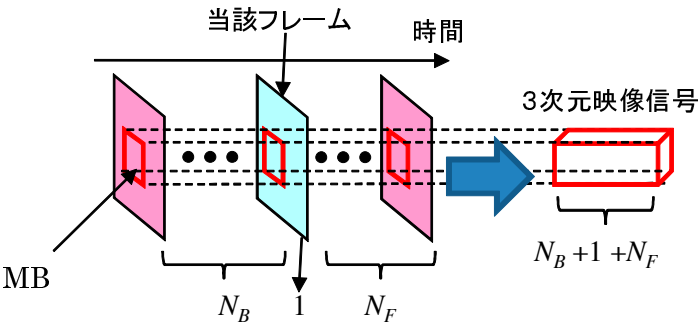

図 23 次元映像信号取得

Extraction of spatial-temporal picture data.

トした結果，網点部の外にある要素は人間の目に知覚でき ない.

すなわち，図 1 に示した時空間視覚特性を用いることに より，視覚上の信号の重要性を局所的に表現することがで きるようになることを意味する。

\section{2 符号化における残差信号への時空間視覚特性モテ ル適用}

本節では，前節の表現に基づき，これを符号化に適用す る方法について述べる.

まず，鋭/鈍繰り返しの原理に従い，以下の処理は 1 枚お き（先頭を 0 フレームとして奇数番目のフレームのみ）に 行われるものとする。また，符号化に適用することを考え ると，処理が適用されないフレームに誤差が伝搬すること は望ましくない。そこで，空間解像度を落とす処理が適用 されるフレームのピクチャタイプは，文献 8) を踏襲し，符 号化時参照されることのない B フレームに限定する.

本処理の対象となるフレームの各 MBに対し，前節で述 ベた通り，原画像からその前後数フレームにわたり 3 次元 映像信号を作成し，それに 3 次元 FFTを適用する。一般 的に自然動画像の 3 次元 FFT の結果は図 $3(\mathrm{a})$ に示す通り, 折り返しを除くと原点を通る 1 本の直線に集中する ${ }^{10)}$. こ のスペクトル画像に対し，図 1 の視覚通過帯域をあてはめ たものを模式的に描くと図 $3(\mathrm{~b})$ のようになる。同図の中央 部にある四角錐が視覚通過帯域であり，図 1 のく部に相当 する。この視覚通過带域より外にある周波数成分が人間の 目には知覚できない部分となる。

この原理に従い，原信号において，視覚通過帯域外の信 号を除去した上で符号化することも可能である。しかし， 鈍フレームにおける動き補償予測誤差符号化を考慮した場 合，参照先に視覚通過帯域外の信号が含まれるため，結果， 帯域外の成分を符号化することになる。一方，符号化時に この原理に従った処理を適用することは，主観画質を保持 したまま，符号化対象となる信号に対し高域に発生した係 数を除去することになる。したがって，本原理を符号化処 理内に適用する方が性能の向上に寄与することが期待でき る.ここで，変換，量子化された動き補償予測誤差信号の 具体例を図 4 に示す。同図の通り，実際に符号化対象とな る信号 (残差信号) の高域に係数が発生しており，これを 


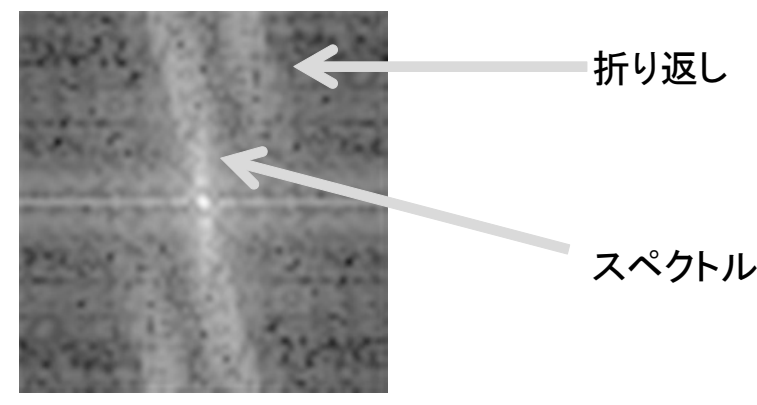

(a) ある MB の FFT スペクトラム (簡単のため, 水平一時間周波数特性のみ提示)

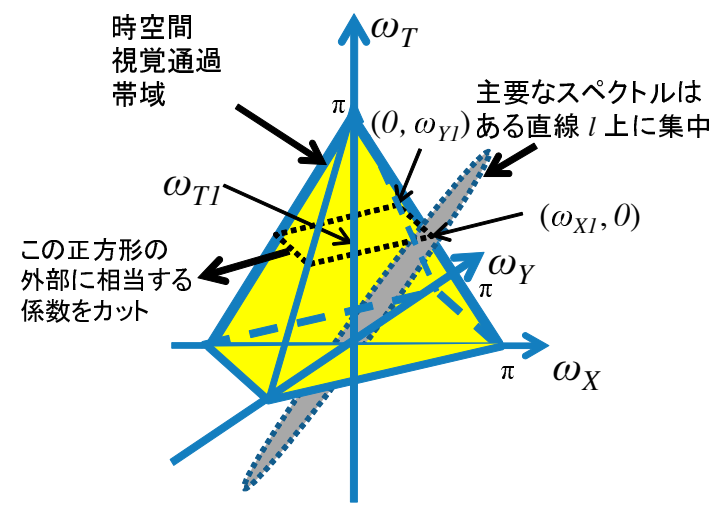

(b) 係数除去方法（簡単のため視覚通過帯域は $\omega_{T}>0$ のみを記載）

図 3 時空間特性の符号化への適用

Coding scheme based on spatial-temporal property

\begin{tabular}{|r|r|r|r|}
\hline 1 & -3 & -4 & -1 \\
\hline-7 & 1 & 2 & 0 \\
\hline-5 & -2 & 4 & 0 \\
\hline-1 & 2 & 0 & 0 \\
\hline
\end{tabular}

\begin{tabular}{|r|r|r|r|}
\hline-8 & 5 & 1 & 2 \\
\hline-5 & 2 & -3 & 0 \\
\hline 4 & -1 & 0 & 0 \\
\hline 1 & 0 & 0 & 0 \\
\hline
\end{tabular}

図 4 シーケンス Colorful World のあるブロックの動き補償 予測誤差信号を変換・量子化した例. マーキングされた 係数が提案法により削除可能となる。

The transformed and quantized MC prediction error obtained from the sequence "Colorful World". Highlighted coefficients are eliminable by the proposed method.

符号化対象から外すことで，主観画質を保持したまま符号 量が削減可能となることを意味する.

そこで，符号化対象から外すことのできる係数を以下の ように求める. まず, $\omega_{X}=0$ 平面, および $\omega_{Y}=0$ 平面そ れぞれに対し，文献 10)にならい，ピーク值をとる直線スぺ クトルを求める。次に，それぞれの直線の傾きを用いて，図 $3(\mathrm{~b})$ にある直線 $l$ を表現する. その後, 求められた直線 $l$ と 時空間通過帯域を示す四角錐との交点を求め，その交点の $\omega_{T}$ 座標 $\omega_{T 1}$ を用いて, 時空間通過帯域を示す四角錐と平 面 $\omega_{T}=\omega_{T 1}$ が交わる正方形を求める. この正方形の頂点 を $\left( \pm \omega_{X 1}, 0\right),\left(0, \pm \omega_{Y 1}\right)$ (ただし, $\left.\omega_{X 1}>0, \omega_{Y 1}>0\right)$ とするとき, $\left|\omega_{X}\right|>\omega_{X 1}$ または $\left|\omega_{Y}\right|>\omega_{Y 1}$ に相当する正 方形の外部の変換係数を伝送しない. すなわちゼロとする.

なお， $8 \times 8 \mathrm{DCT}$ や $4 \times 4$ 整数変換のマトリクスへの マッピングについては，以下の通り行うこととする.
（1） FFTによる遮断周波数に相当する係数のインデッ クス $N$ を求める.

（2）FFTを適用した場合と比較し, energy compaction ratio が初めて大きくなる係数のインデッ クス $M$ を求める。具体的には以下の通り行う.

IFFT および逆整数変換/IDCT の際にジグザグス キャンにより $n$ 番目の係数まで逆変換，すなわち， $n+1$ 番目以降の係数を零にして逆変換し得られる 結果を，ブロック内の位置のインデックス $i$ を用い て，それぞれ $\operatorname{IFFT}(i, n), I Z T(i, n)$ とする。この とき,

$$
\begin{array}{r}
\frac{\sum_{i=0}^{L_{Z}^{2}-1} I Z T^{2}(i, M)}{\sum_{i=0}^{L_{Z}^{2}-1} I Z T^{2}\left(i, L_{Z}^{2}\right)} \\
\geqq \frac{\sum_{i=0}^{L_{F}^{2}-1} I F F T^{2}(i, N)}{\sum_{i=0}^{L_{F}^{2}-1} I F F T^{2}\left(i, L_{F}^{2}\right)}
\end{array}
$$

となる最小の $M$ を選択する。ただし，空間方向 の $\mathrm{FFT}$ 適用単位を $L_{F} \times L_{F}$ （後述），逆整数変 換 $/ \mathrm{IDCT}$ 適用単位を $L_{Z} \times L_{Z}$ (逆整数变換のとき $L_{Z}=4$, IDCT のとき $\left.L_{Z}=8\right)$ とする.

残差信号に着目するメリットとして，以下の 2 点が挙げ られる。

- FFTにより求められた空間スペクトラムと、整数 /DCT 変換係数において必要となる次数を対応づけるこ とにより，変換係数の高域成分を削除することができるた め，符号量削減につながる。

・復号側に一切変更を加える必要がないため，1 フレー ムおきに別々の処理をする必要が生じず，デコーダ設計の 観点で有用である.

また，本来は復号画像に対し 3 次元 FFT を適用すべき である。すなわち，全体を 2 パス構造とし，1 パス目に通 常の符号化を行い，2 パス目として，そこで得られる復号 画像に対し FFT を適用し，その結果に基づき 1 パス目で 得られたビットストリーム中の变換係数を除去する方法で ある．ところが，2 パス符号化は遅延につながるため， 1 パスで符号化できること，すなわち，原画像に直接 3 次元 FFT を適用できることが望ましい。そこで，両者の違いを 確認するための予備実験を行った。その結果を 図 5 に示す.

同図より，本処理を原画像に適用した場合，前述の復号 画像に適用する場合と比較しほほ同等，もしくは，仮に異 なっているとしても，変換係数が遮断されにくくなる，す なわち劣化が起こりにくくなることがわかる．紙面の都合 上，ここでは単一シーケンスの結果のみ示しているが，複 数種類のテストシーケンスに対し，同等の結果が得られる ことを確認した。

したがって，時空間周波数スペクトルは 1 パス，2 パス の場合でそれぞれ大きく変わらないため，1 パスで符号化 を行う，すなわち，原画像に直接 3 次元 FFT を適用する こととし，この処理を符号化モード選択部に適用する. 


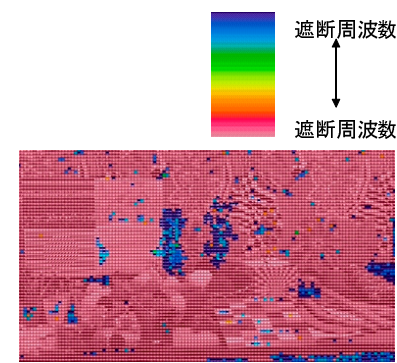

(a)原画像に適用 $(1$ パス)


(固定QP: 35で符号化復号) (b)復号画像に適用 (2パス)

図 53 次元 $\mathrm{FFT}$ 適用対象の違いによる時空間周波数スペク トル分布

A difference of spatial-temporal spectrum depending on the FFT target image.

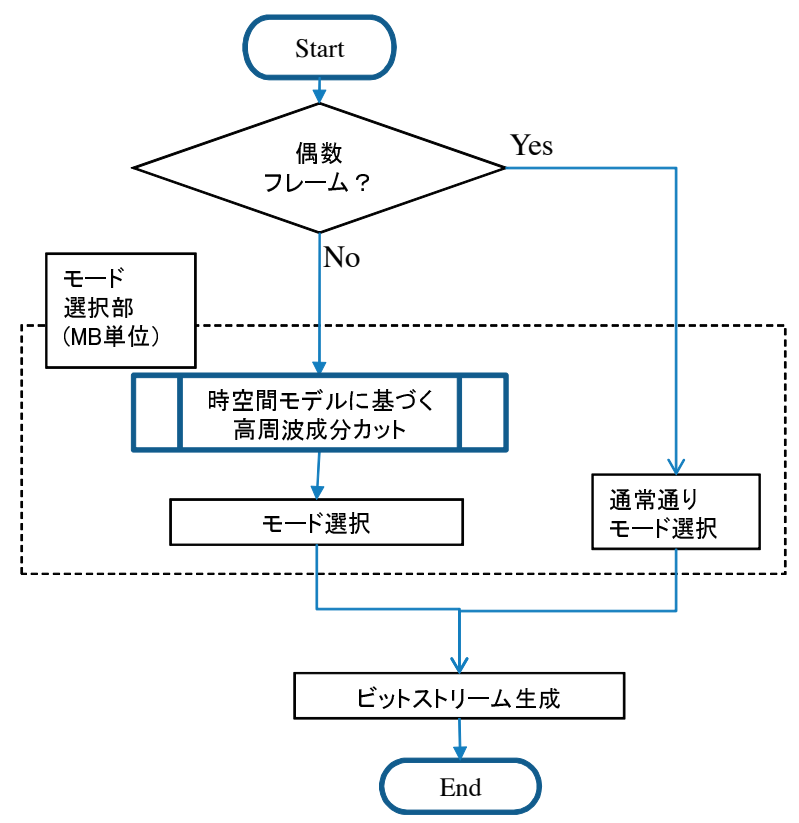

(a) 全体図

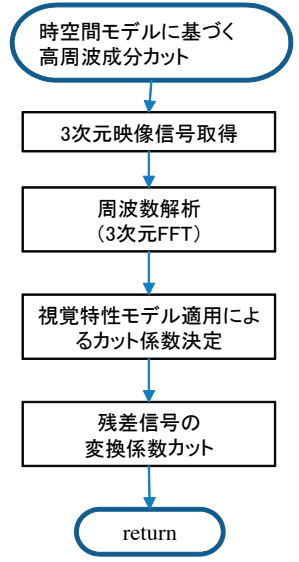

(b) 時空間モデルに基づく高周波成分カット部

図 6 提案法の処理の流れ ((b) は (a)の一部である) A flow of our proposed method (The figure (b) is a part of the figure (a)).

以上をまとめると，全体の流れは図 6 のようになる。な お，候補となる全符号化モードについて高周波成分カット を行うこととする.
表 1 実験条件

Experimental condition.

\begin{tabular}{|c|c|c|}
\hline & 項目 & "内容 \\
\hline \multirow{5}{*}{ 符号化 } & & $600(10 \mathrm{sec})$ \\
\hline & $\begin{array}{l}\text { フレーム数, } \\
\text { 構造 }\end{array}$ & $\begin{array}{c}I[B] B[B] P(\mathrm{M}=4, \mathrm{~N}=32), \text { 階層 } \mathrm{B}, \\
{[B] \text { が提案手法適用フレーム }}\end{array}$ \\
\hline & $\mathrm{QP}$ & $\begin{array}{l}\text { 各フレーム内で固定，かつ, } \\
\text { 階層ごとにインクリメント } \\
\text { (文献 11) を踏襲. ) }\end{array}$ \\
\hline & Profile@Level & High@L4.2 \\
\hline & $\begin{array}{l}\text { エントロピー } \\
\text { 符号化 }\end{array}$ & CABAC \\
\hline \multirow[t]{4}{*}{$\begin{array}{l}\text { 符号化対象 } \\
\text { テスト信号 }\end{array}$} & シーケンス & $\begin{array}{c}\text { 本会ハイビジョン・システム } \\
\text { 評価用標準動画像第 } 2 \text { 版 } \\
\text { 全 } 6 \text { 種類 }(\text { 図 } 7, \text { 表 2) }\end{array}$ \\
\hline & 色空間 & $\begin{array}{c}\text { YUV } 4: 2: 0 \\
(4: 2: 2 \text { から色差信号を間引き) }\end{array}$ \\
\hline & ビット深度 & 8 bit \\
\hline & $\begin{array}{c}\text { 映像 } \\
\text { フォーマット }\end{array}$ & $\begin{array}{c}1920 \times 1080 \\
60 \mathrm{p}\end{array}$ \\
\hline
\end{tabular}

\section{4. 実験および考察}

前章の提案符号化方式の有効性を検証するため，実験を 行う。実験では, $\mathrm{AVC} / \mathrm{H} .264$ 符号化に前節の提案手法を 適用した場合と, AVC/H.264 符号化方式 (JM ver.17.2) をそのまま適用した場合を比較する。実験条件を表 1 に 示す。なお，量子化パラメータ QP は両方式で同じ值， かつ, シーケンス全体で固定とし, 各シーケンスに対し, 6.25Mbps, $12.5 \mathrm{Mbps}$ の 2 通りのビットレートに対し, そ れぞれ $\mathrm{AVC} / \mathrm{H} .264$ 符号化方式をそのまま適用した場合に 最も近くなる $\mathrm{QP}$ をそれぞれ選択した（選択された $\mathrm{QP} は$ 表 4 に記載)。すなわち, 提案法適用時は $\mathrm{AVC} / \mathrm{H} .264$ 適 用時と比較し, 係数を除去している分, 原画像との信号值 の誤差は大きくなる.

また，視覚特性モデルを決定する 3 次元 FFT の次数は， 空間方向 $16 \times 16$ 次, 時間方向 8 次 (図 2 で $N_{F}=1, N_{B}=6$ ) を適用した。これらの值は, 複数の次数候補から選択した ものであるが，その詳細は付録 $\mathrm{A}$ を参照されたい。つまり 本方式に基づく原理遅延は 1 フレーム分のみである。

まず，提案方式では 1 フレームおきに処理を適用してい るため，それがフリッカとなって検知される可能性が懸念 される，そのため，本提案手法の適用によりフリッカが生 じないことを検証する必要がある。そこで，AVC/H.264 と 提案手法の両符号化復号画像に対し，フリッカ尺度 ${ }^{15)}$ を測 定した。結果を表 3 に示す。本尺度は，原画像，符号化復 号画像の両者に対し，隣接する 2 フレーム間において，同 一局所領域 $(\mathrm{MB})$ ごとのフレーム間差分をそれぞれ求め, その差分電力を平均したものである。したがって，その值 が大きいほどフリッカが生じていることを意味するが，同 表より, AVC/H.264 と提案法の双方で有意な差異がない, すなわち，提案手法によりフリッカを生じさせていないこ とが確認できる. 有意な差異が生じなかった理由として, 高 域信号值はエネルギーとしては一般に大きくなく, 差分電 カへの影響がほとんどなかったためと考えられる. 


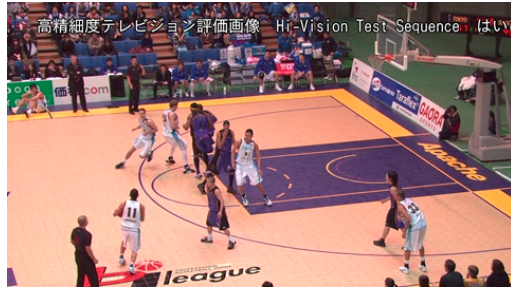

Basketball

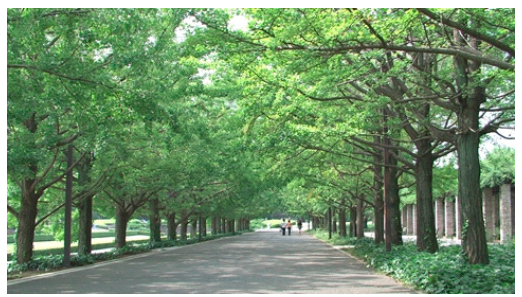

Ginkgo trees

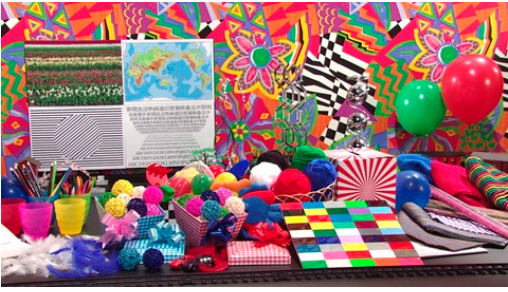

Colorful world

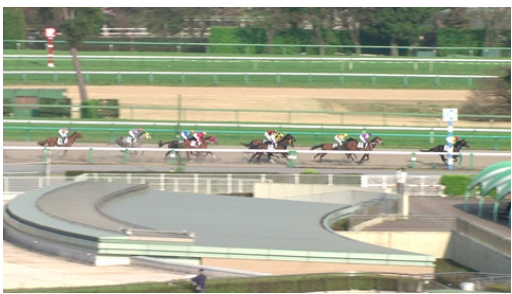

Horse racing (Dirt)

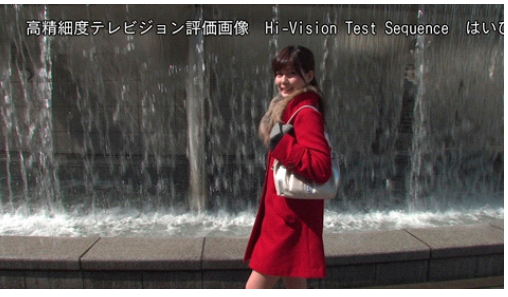

Fountain

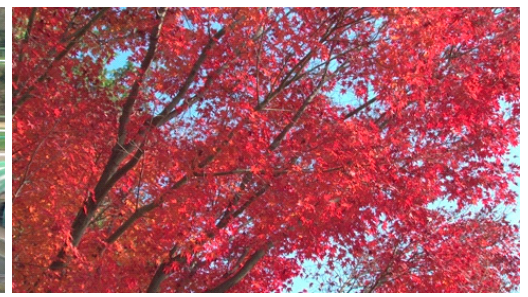

Red leaves

図 7 評価用画像

Test sequence.

表 2 評価用画像の特徵

Feature of test sequences.

\begin{tabular}{|c|c|}
\hline Seq. & Feature \\
\hline Basketball & $\begin{array}{l}\text { バスケットボール試合を映した映像. } \\
\text { ボールの動きにあわせたパンを伴う. }\end{array}$ \\
\hline $\begin{array}{l}\text { Colorful } \\
\text { world }\end{array}$ & $\begin{array}{l}\text { カレンダー, 汽車などの物体がそれぞれ独立に動く映像. } \\
\text { 汽車の動きにあわせたパンを伴う. }\end{array}$ \\
\hline Fountain & $\begin{array}{l}\text { 噴水の前を女性が歩く場面を映した映像. } \\
\text { 女性の歩きにあわせたパンを伴う。 }\end{array}$ \\
\hline $\begin{array}{l}\text { Ginkgo } \\
\text { trees }\end{array}$ & $\begin{array}{l}\text { 緑色の銀杏並木を映した映像. カメラはズームインする. } \\
\text { カメラや中の物体の動きは非常に緩やかだが, 映像は精細. }\end{array}$ \\
\hline $\begin{array}{l}\text { Horse } \\
\text { racing }\end{array}$ & $\begin{array}{l}\text { 競馬を映した映像. } \\
\text { 馬の動きも大きく，それにあわせたパンを伴う. }\end{array}$ \\
\hline $\begin{array}{l}\text { Red } \\
\text { leaves }\end{array}$ & $\begin{array}{l}\text { 紅葉の中を女性が歩く映像. } \\
\text { 緩やかなチルトを伴う. }\end{array}$ \\
\hline
\end{tabular}

表 3 フリッカ尺度 ${ }^{15)}$ による評価

Evaluation results by flicking measure ${ }^{15)}$.

\begin{tabular}{c|r|r|r|r}
\hline \hline \multirow{2}{*}{ Seq. } & \multicolumn{2}{|c|}{$6.25 \mathrm{Mbps}$ 相当 } & \multicolumn{2}{|c}{$12.5 \mathrm{Mbps}$ 相当 } \\
\cline { 2 - 5 } & AVC/H.264 & 提案法 & AVC/H.264 & 提案法 \\
\hline Basketball & 840.06 & 839.69 & 820.54 & 819.80 \\
\hline Colorful world & 717.60 & 713.52 & 663.11 & 663.12 \\
\hline Fountain & 1065.20 & 1063.29 & 1023.65 & 1022.08 \\
\hline Ginkgo trees & 467.79 & 472.19 & 395.17 & 397.22 \\
\hline Horse racing & 667.99 & 677.16 & 487.50 & 492.73 \\
\hline Red leaves & 186.49 & 186.43 & 174.30 & 174.32 \\
\hline
\end{tabular}

次に，提案手法により主観画質が劣化するか否かを確認 するために主観評価実験を行った，画質評価には二重刺激 連続品質尺度法（DSCQS） ${ }^{12)}$ を用いた。本評価実験にお ける被験者は非専門家 15 名，視距離は $3 \mathrm{H}$ である。ただ し, 本稿では, 文献 13)14) 同様, 通常の AVC/H.264 で符 号化された信号を基準信号とし，それに対し提案手法によ り符号化された信号を評価した。結果を図 8 に示す.同図 でDMOS(Differential MOS) とは, 両方式を評価するこ とにより得られた MOS 值 (0-100) の差分（(提案手法によ り得られる信号の評価値 $)-($ 基準信号の評価値 $))$ であるこ とを意味する。な拉, 文献 12) に従い被験者のスクリーニ ングを適用した結果, 全 15 名中 2 名の結果が棄却された。 同図より，各シーケンスに扔けるDMOS の平均值を見る

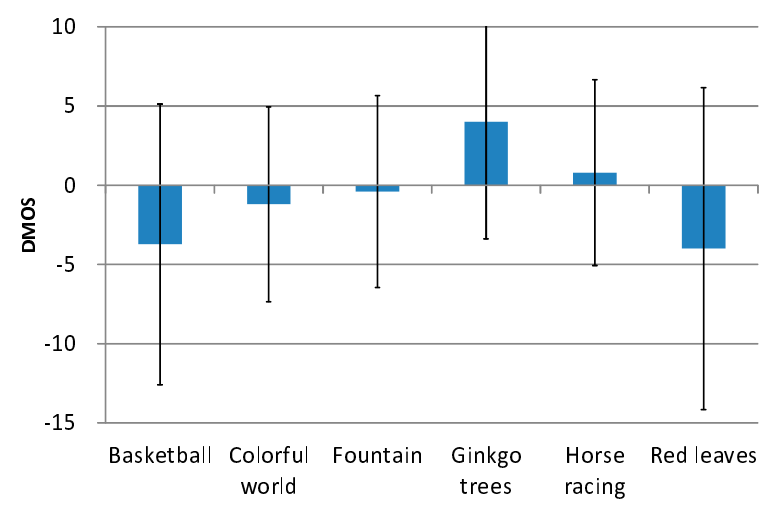

図 $812.5 \mathrm{Mbps}$ 符号化時の主観評価実験結果（誤差線はそれ ぞれ $95 \%$ 信頼区間を示す)

Subjective assessment results for each $12.5 \mathrm{Mbps}$ video sequence (Each error bar indicates its $95 \%$ confidential interval).

と，両方式の結果に有意な差異がないことがわかる．さら に, DMOSで $20 \%$ の差は, MOS の評価語が一つ変わるこ とを意味する（例えば,「良い」一「普通」の違い）が，全 シーケンスに対し，95\%信頼区間を含めてもそこまでの差 異はなく，15\%未満にとどまっていることが確認できる，以 上より，提案方式により，1フレームおきに残差信号を除 去したとしても，AVC/H.264符号化時と比較し画質が劣 化していない，もしくは，画質が若干劣化してもそれは許 容できる範囲であることがわかる.

ここで, 本結果を踏まえ, 提案方式で適用されている内 容について再度振り返る。提案方式は AVC/H.264 符号化 方式に対し, 視覚通過帯域の概念を設け, 符号化時に同带域 に含まれない残差成分を遮断し符号化したものである。し たがって，視覚通過带域外に，遮断された残差成分に相当 する雑音が重畳されることを意味する。これに対し，上記 の結果が得られたことは,「視覚通過带域外に含まれる雑音 は無視できる」ことを示唆している. 


\begin{tabular}{|c|c|c|c|c|c|c|c|c|c|c|c|c|c|c|}
\hline \multirow[b]{3}{*}{ Sequence } & \multicolumn{7}{|c|}{ (a) $6.25 \mathrm{Mbps}$ 相当 } & \multicolumn{7}{|c|}{ (b) $12.5 \mathrm{Mbps}$ 相当 } \\
\hline & \multirow[b]{2}{*}{ QP } & \multicolumn{3}{|c|}{ 全体 } & \multicolumn{3}{|c|}{$\begin{array}{c}\text { 奇数フレーム } \\
\text { (提案法適用フレーム) }\end{array}$} & \multirow[b]{2}{*}{ QP } & \multicolumn{3}{|c|}{ 全体 } & \multicolumn{3}{|c|}{$\begin{array}{c}\text { 奇数フレーム } \\
\text { (提案法適用フレーム) }\end{array}$} \\
\hline & & $\begin{array}{c}\text { AVC/ } \\
\text { H.264 } \\
\text { [Mbps] }\end{array}$ & $\begin{array}{c}\text { 提案法 } \\
\text { 適用 } \\
{[\mathrm{Mbps}]}\end{array}$ & $\begin{array}{c}\text { 符号量 } \\
\text { 削減率 } \\
{[\%]}\end{array}$ & $\begin{array}{c}\text { AVC/ } \\
\text { H.264 } \\
{[\mathrm{Mbps}]}\end{array}$ & $\begin{array}{c}\text { 提案法 } \\
\text { 適用 } \\
{[\mathrm{Mbps}]}\end{array}$ & $\begin{array}{c}\text { 符号量 } \\
\text { 削減率 } \\
{[\%]} \\
\end{array}$ & & $\begin{array}{c}\text { AVC/ } \\
\text { H.264 } \\
\text { [Mbps] }\end{array}$ & $\begin{array}{c}\text { 提案法 } \\
\text { 適用 } \\
\text { [Mbps] }\end{array}$ & \begin{tabular}{|c} 
符号量 \\
削減率 \\
{$[\%]$}
\end{tabular} & $\begin{array}{c}\text { AVC/ } \\
\text { H.264 } \\
{[\mathrm{Mbps}]}\end{array}$ & $\begin{array}{c}\text { 提案法 } \\
\text { 適用 } \\
\text { [Mbps] }\end{array}$ & $\begin{array}{c}\text { 符号量 } \\
\text { 削減率 } \\
{[\%]} \\
{[\%]}\end{array}$ \\
\hline Basketball & 33 & 6.51 & 5.74 & 11.9 & 1.95 & 1.18 & 39.5 & 28 & 12.93 & 11.06 & 14.4 & 4.19 & 2.32 & 44.6 \\
\hline Colorful world & 35 & 6.25 & 5.44 & 13.0 & 1.65 & 0.84 & 49.3 & 31 & 11.81 & 9.88 & 16.4 & 3.58 & 1.65 & 54.0 \\
\hline Fountain & 39 & 6.70 & 5.77 & 13.9 & 2.66 & 1.73 & 35.0 & 35 & 12.21 & 10.16 & 16.8 & 4.98 & 2.93 & 41.1 \\
\hline Ginkgo trees & 42 & 6.17 & 5.67 & 8.2 & 1.49 & 0.99 & 33.8 & 38 & 12.08 & 10.81 & 10.5 & 3.13 & 1.86 & 40.6 \\
\hline Horse racing & 32 & 6.11 & 5.27 & 13.7 & 1.98 & 1.14 & 42.4 & 27 & 12.86 & 10.47 & 18.6 & 4.55 & 2.17 & 52.5 \\
\hline Red leaves & 36 & 6.28 & 5.45 & 13.2 & 1.51 & 0.68 & 55.0 & 32 & 12.15 & 10.20 & 16.1 & 3.16 & 1.21 & 61.8 \\
\hline
\end{tabular}

次に，提案方式による符号量の削減効果を表 4 に示す. 同表より，6.25Mbps のとき全シーケンスで平均 8-13\%， $12.5 \mathrm{Mbps}$ のとき全シーケンスで平均 10-18\%の符号量削 減が達成できていることがわかる，参考までにこの值を文 献 7) と比較すると, 同文献では対象としている視環境，符 号化実験環境が異なるため，同一レベルで評価することが できないが，符号量削減率としてはほぼ同等の值が得られ ていることがわかる。ささらに，今回提案手法を適用したフ レーム，すなわち，(先頭を 0 フレームとして）奇数番目の フレームに限定すると，40-50\%の符号量削減が達成できて いる．ここで，ビットレートが高いほど符号量削減できる のは, H.264符号化の場合，より多くの高周波成分が存在 しているためである。ところが，表 4 の (a)6.25Mbps 相 当,(b) $12.5 \mathrm{Mbps}$ 相当の符号量削減率をそれぞれ比較する と，ビットレートを倍にしても符号量削減率が劇的に大き くなっていないことを確認できる. 実際に, ビットレートを $50 \mathrm{Mbps}$ 程度にして実験してみても符号量削減率は $20 \%$ 強 であった。これは，符号化レートが高くなると，残差信号 に符号量を多く割り当てることができる一方，被参照画像 の誤差が小さくなるため, 参照画像の予測誤差もそれにあ わせて小さくなる，すなわち，残差信号が小さくなり，両 者の効果が相殺されているためである.

\section{5. むす び}

本稿では, 高フレームレート動画像に対し, その符号化 効率を向上させるために，局所的な時空間視覚特性に基づ き，1フレームおきに高周波成分を除去する方式を提案し た. その際に, 符号化前の原信号や復号信号の高周波成分 を除去するのではなく，イントラ予測，もしくは動き補償 予測の残差信号変換係数のそれを除去している。実験の結 果，対象とするシーケンスおよび符号化ビットレートにも 依存するが，主観画質を落とすことなく平均 10～15\%の 符号量削減ができ，映像内の動きが大きい，もしくはビッ トレートが高い場合に，その削減率が高くなることを確認 した。

今後の課題として, 本稿では $60 \mathrm{p}$ の画像に対してのみ評 価を行ったが，フレームレートが $60 \mathrm{~Hz}$ よりも高い場合の 本提案方式の適用可能性を視覚特性モデルを考慮し確認す
る予定である。また，本稿では，AVC/H.264への適用に ついて述べたが，例えば，スケーラブル符号化 (SVC) にお いて，下位レイヤからの予測による残差信号に前述の視覚 特性モデルを適用することも可能であると考えられる。こ のような異なる符号化方式への適用可能性についても確認 していく予定である.

本研究は, 独立行政法人情報通信研究機構による委託研 究「超高精細映像符号化技術に関する研究開発」として実 施したものである.

\section{〔文献〕}

1）“スーパーハイビジョン時代の映像 フレーム周波数は $60 \mathrm{~Hz}$ 以上へ”, 映像新聞, 第 1961 号 (平成 22 年 7 月 26 日), pp.5 (2010)

2) SMPTE 424M-2006, “SMPTE Standard for Television - 3 Gb/s Signal/Data Serial Interface”, Society of Motion Picture and Television Engineers (2006)

3）本山，井對，猪股，“1080/60p 対応 H.264/MPEG-4 AVC ビデオコー デックの開発”, 2010 信学ソ大, A-4-9, pp.A-78 (2010)

4) Y. Bandoh, K. Hayase, S. Takamura, K. Kamikura, and Y. Yashima, “Theoretical Modeling of Inter-frame Prediction Error for High Frame-rate Video Signal”, IEICE Trans. on Fundamentals of Electronics, Communications and Computer Sciences, E91-A, 3, pp. 730-739 (2008)

5) Y. Bandoh, S. Takamura, H. Jozawa, and Y. Yashima, "Generalized Theoretical Modeling of Inter-frame Prediction Error for High Frame-rate Video Signal Considering Integral Phenomenon", IEICE Trans. on Fundamentals of Electronics, Communications and Computer Sciences, E93-A, 8, pp. 14421452(2010)

6) A. Fujibayashi and C. S. Boon, “A Masking Model for Motion Sharpening Phenomenon in Video Sequences”, IEICE Trans. on Fundamentals of Electronics, Communications and Computer Sciences, E91-A, 6, pp. 1408-1415 (2008)

7) A. Fujibayashi and C. S. Boon, "Application of Motion Sharpening Effect in Video Coding”, Proc. IEEE ICIP 2008, pp.2848-2851 (2008)

8）吹抜，“鋭/鈍繰返し画像の解明とフレーム内挿倍速表示（TFI）などへ の応用～視知覚信号処理工学の発展～”, 映情学誌, 63, 4, pp.549-552 (2009)

9) S. V. Ramachandran, M. V. Rao and R. T. Vidyasagar, “Motion sharpening during movement perception”, Mag. Perception, 3, pp. 97-98 (1974)

10）中山, 橋本, 大照, “時空間フーリエ変換による画像の動領域抽出”, 第 46 回情処学全大, pp.173-174 Mar. (1993)

11) TK Tan, G. Sullivan, T. Wedi, "Recommended simulation conditions for coding efficiency experiments", ITU-T SG16/Q.6, 35th VCEG Meeting, VCEG-AI10 (2008)

12) ITU-R Rec. BT.500-11, “Methodology for the subjective assessment of the quality of television pictures" , (2002)

13) M. Hasnaoui, M. Mitrea, M. Belhaj, and F. Preteux, “Visual quality assessment for motion vector watermarking in the MPEG4 AVC domain " , Proc. VPQM 2010 (2010)

14) I.W.Agung and P. Sweeney, "Video scene characteristic detection to improve digital watermarking transparency”, Proc. IEEE 
ICIP 2002, 2. pp. 146-152 (2002)

15) X. Fen, W. Gao, Y. Lu, D. Zhao, “Flicking reduction in all intra frame coding”, ISO/IEC JTC1/SC29/WG11 and ITU-T SG16 Q.6, JVT-E070 (2002)

\section{〈付録〉}

\section{A. 実験で用いる 3 次元 FFT の次数}

本節では，実験で用いている 3 次元 FFT の次数の妥当 性について検証する。

\section{A. 1 空間方向適用範囲}

提案手法は符号化モード判定で適用されるため，MB 単 位（16x16）で処理ができることが望ましい，ところが，局 所単位ごとに FFT を適用すると，周波数分解能が低くな り, 必要とする特性が得られなくなる懸念がある.

そこで，空間的に FFT を適用する範囲の大小により，求 められる遮断周波数がどのように変化するかについて検証 する. 3 次元 FFT 時の空間方向のサイズとして以下の 3 パ ターンを用意し, 上記各パターンの 3 次元 FFT から求め られる遮断周波数がどのようになるかを複数のシーケンス に対し評価した。

$\begin{array}{ll}\text { ・パターン } 1: & \left.16 \times 16 \text { (1 } 1^{2} \mathrm{MB} \text { 分 }\right) \\ \text { ・パターン } 2: & \left.80 \times 80 \text { ( } 5^{2} \mathrm{MB} \text { 分 }\right) \\ \text { ・パターン } 3: & 144 \times 144\left(9^{2} \mathrm{MB} \text { 分 }\right)\end{array}$

付・図 1 にいくつかのシーケンスに対する結果を示す。同 図より, FFT の適用範囲が変化したとしても，遮断周波数 は大きく変化していないことがわかる.

また，遮断周波数が変わった個所においても，適用領域 が広くなるに従い，遮断周波数がより低くなる傾向がある ことがわかる。これは，FFTを広い範囲で適用した場合 より狭い範囲で適用した方が，より安全に係数を遮断する ことができる, すなわち, 変換係数をカットしすぎること がないことを意味している。逆に，適用領域が広くなるに 従い, 遮断周波数がより高くなった個所も若干存在するが, そのような個所に着目して主観評価を行った結果, 主観画 質として劣化が生じないことを確認した。ゆえに本提案手 法では，MB 単位で FFTを適用することとした。

\section{A. 2 時間方向適用範囲}

全処理時間の短縮のためには，時間方向についても空間 方向同様処理単位が小さい方が望ましい. ところが, 適用 時間 $T$ を短くすると周波数分解能が低くなり，必要とする 特性が得られなくなる懸念がある。本研究において，3 節 にも述べた通り，フレーム内局所領域ごとに実効時間周波 数を求められることが理想だが，次数 $T=2,4$ 程度の場合， 必要とする精度を得ることが難しくなる．例えば， $T=4$ とすると, 図 $3(\mathrm{~b})$ において, 時間周波数軸 $\omega_{T}$ 方向は 4 通 りにしか評価できない。その結果が (1) 式に基づき， $4 \times$ 4 , もしくは $8 \times 8$ の変換係数に適用されることを考慮する と, 4 通りでは精度が低いと考えられる．以上を考慮する と, $T=8$, 可能であればそれ以上とすることが望ましい. 一方，冒頭に述べた通り，Tが小さくなっても同じ特性



パターン2
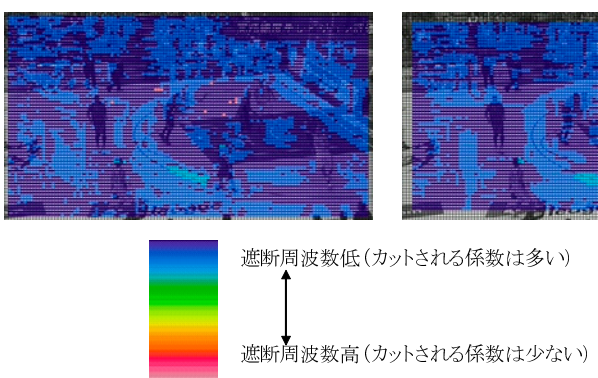

付・図 1 空間方向 FFT 適用範囲と遮断周波数の関係 Relationship between cutoff frequency and FFT range in spatial domain.

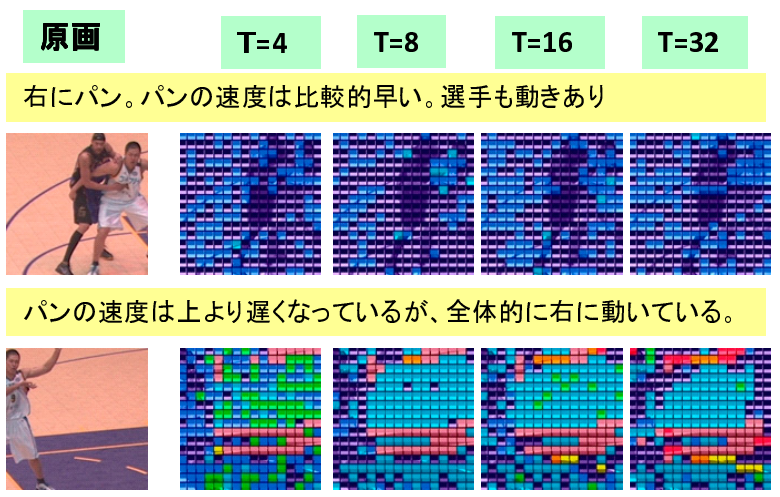

画面は固定で、動きなし。選手は動いている。


付.図 2 時間方向 FFT 適用範囲と遮断周波数の関係 (凡例は 付·図 1 と同じ)

Relationship between cutoff frequency and FFT range in temporal domain.

が得られるのであれば，Tは小さい方が望ましい.

そこで, 空間方向における検証方法同様, 必要充分な精 度が得られる時間方向の次数 $T$ がどのくらいであるのかを 確認するために $T$ を高い方から $32,16,8,4$ と変えどのよ うに変化するかを確認した。結果を付・図 2 に示す。同図よ り, $T=32,16,8$ 次の場合は非常に近い結果が得られてい るが, $T=4$ 次にすると遮断周波数が高くなる個所が多く 現れることが確認できる。そこで，ここでは 8 次のケース を採用することとする。

ところで，8次を適用する場合も，付·図 2 に示した通り， $N_{F}$ と $N_{B}$ をどのようにすべきかを検討する必要がある. 同図の結果は $N_{F}=N_{B}+1$ (例えば, 4 次の場合 $N_{F}=1$, $N_{B}=2,8$ 次の場合 $\left.N_{F}=3, N_{B}=4\right)$ としたものである 


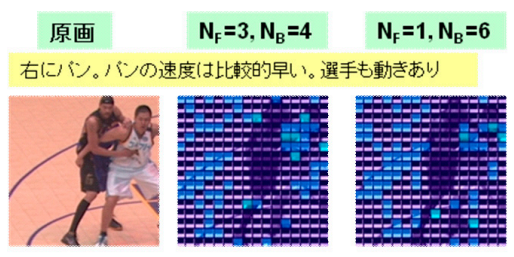

パの速度は上より遅くなっているが、全体的に右に動いている。

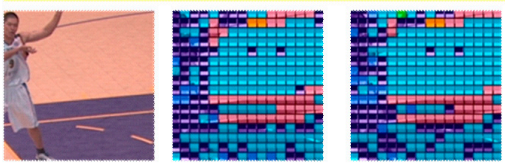

画面は固定で、動きない。選手は動いている。

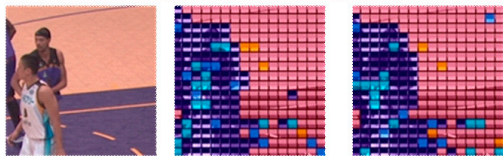

付·図 3 時間方向 FFT8 次の場合の $N_{F}, N_{B}$ と遮断周波数 の関係 (凡例は付·図 1 と同じ)

Relationship between cutoff frequency and $N_{F}, N_{B}$ in case of $N_{F}+N_{B}+1=8$

が， $N_{F}$ が大きくなると，符号化時の原理遅延となるため, $N_{F}$ の值は小さい方が望ましい，そこで，8次の場合， $N_{F}$ $=1, N_{B}=6$ とした場合に，上記と比較しどのようになる かについて評価した，結果は付・図 3 のとおりである。同図 より $N_{F}=1, N_{B}=6$ の場合は, $N_{F}=3, N_{B}=4$ と比較しほ ぼ違いがないことが確認できる。以上から $N_{F}=1, N_{B}=6$ を適用することとした。



たがきささういち 1996 年，東京工業大学工学部情報工 学科卒業, 1998 年, 同大学大学院修士課程修了. 同年, 国際電信電話 (株) (現 $\operatorname{KDDI}($ 株)) に入社. 以来, 動画 像符号化，音響コンテンツセキュリティ，処理に関する 研究・開発に従事. 現在, 同社技術戦略部課長. 正会員。


子工学科卒業, 1999 年, 同大学大学院修士課程修了. 同 年 4 月, $\mathrm{KDD}$ (株) (現 $\mathrm{KDDI}($ 株)) 入社。以来, 同社 研究所にて映像品質の客観評価技術, 映像伝送品質監視 システムの研究開発に従事. 現在, (株) KDDI 研究所超 臨場感通信グループ研究主査. 正会員。

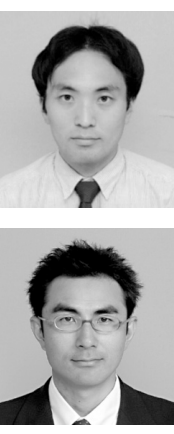

内势藤整 1994 年, 早稲田大学理工学部電子通 信学科卒業, 1996 年, 同大学大学院修士課程修了. 同 年 4 月, 国際電信電話 (株) (現 $\operatorname{KDDI}($ 株)) 入社. 以 来，HDTV，SDTV の動画像符号化㧍よび伝送方式の 研究・開発に従事, 現在, (株) KDDI 研究所超臨場感通 信グループリーダー．博士 (国際情報通信学). 正会員.

蓜澤茂忠 1990 年, 神戸大学工学部電子工学科 卒業. 1992 年, 神戸大学大学院工学研究科修士課程修了. 同年，国際電信電話 (株) (現 $\operatorname{KDDI}($ 株)）に入社，以来， 動画像符号化，携带電話マルチメディアシステム，コン テンツセキュリティ，3 次元映像処理，コンピュータグラ フィクス関連の研究開発に従事. 現在, (株)KDDI 研究 所メディア・HTML5 応用グループリーダー。博士 (工 学). 正会員.

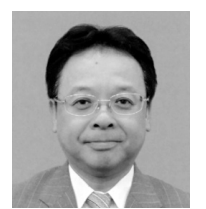

菘㝐本 修うい 1977 年, 北海道大学工学部電子学科 卒業, 1979 年, 同大学大学院修士課程修了. 同年, 国 際電信電話（株）(現 KDDI(株)) 入社。以来，SDTV, HDTV, UHDTV の高能率符号化方式の研究・開発に 従事. 現在, 社団法人日本ケーブルラボ尃務理事. 博士 (工学)。フェロー認定会員。 